\title{
INJIL BAGI SEGALA MAKHLUK \\ Injil Menurut Kejadian 7:9-17 \\ Dan Implikasinya Bagi Tanggung Jawab Manusia Terhadap Ciptaan Lain
}

\section{Herlina Ratu Kenya}

\begin{abstract}
Indeed, the Gospel is the Good News for all beings by virtue of the testimony of the Bible (OT and NT). One of the stories in the OT that caught my attention was about Noah and his family. Only Noah and his family, together with other beings, were the ones that God had saved from the flood hazard punishment due to fact that men's outlook on life at that time was really contrary to will of God. In this story, the Gospel is evident in two words, i.e. come to terms, and never again. Both are God's actions in response to the disoriented human life having its effect in damaging the lives of all creatures. God's action was then responded by Noah with the promise of obedience which was symbolized by the offering. Noah's obedience in keeping the commission from God (Gen 8: 17; 9: 1-7) was like the rose of love for all beings because it contained the dimensions of universal salvation. But in the subsequent course of history, Noah and his descendants again went the wrong way. In the midst of the turbulent misdemeanors of men-which, certainly constitutes a very great destructive force- in the NT we encounter God, whore mains ever faithful to stick to the principle of coming to terms (reconcile), and never again will set such a punishment. God has become man, personified in Jesus Christ who forgives and saves by showing the way as the right direction in human life, through the course of His whole life. Two things from the many right directions that Jesus gave to us are having sufficient food and ownership on a limited basis, as the principles of a simple life yet having adimension of universalsalvation.In this modern era, we confronted with the reality of the human life pattern and direction driven by materialism, consumerism and hedonism becoming increasingly apprehensive. All easily provided, all instantly available, as long as there is money; all easily achieved due to the advancement in science and technology, constitute a great danger that bring destruction to the lives of all humans and other beings if man is not in line with Jesus Christ, the reason for his life, man's natural wealth erode endlessly.The pattern of the life of Jesus forms amoral compass for humans and if this is used then the Good News becomes the property of every creature.
\end{abstract}

KeyWords: God, Human being, Sin, the Gospel, Give thanks, Obedience, Jesus Christ, Simplicity

\begin{abstract}
Abstrak
Sejatinya Injil adalah kabar baik bagi segala makhluk berdasarkan kesaksian Alkitab (PL dan PB). Salah satu kisah dalam PL yang menarik perhatian saya adalah tentang Nuh dan keluarganya beserta makhluk lainnya yang Allah selamatkan dari bahaya hukuman air bah karena orientasi hidup manusia pada masa itu bertentangan dengan maksud Allah. Dalam kisah ini, Injil Nampak dalam dua kata yaitu come to terms dan never again. Keduanya merupakan tindakan Allah dalam menanggapi disoriented hidup manusia yang
\end{abstract}


berdampak terhadap rusaknya kehidupan segala makhluk. Tindakan Allah ini kemudian direspon oleh Nuh dengan janji ketaatan yang disimbolkan oleh persembahan. Ketaatan Nuh dalam menjalankan delegasi Allah (Kej $8: 17 ; 9: 1-7)$ ibarat mawar cinta untuk segala makhluk karena mengandung dimensi penyelamatan universal. Namun dalam sejarah selanjutnya Nuh dan keturunannya kembali salahjalan.Di tengah arus salah jalan manusia - yang sudah tentu memiliki daya rusak yang sangat hebat dalam PB kita berjumpa dengan Allah yang tetap setia berpegang pada prinsip come to terms dan never again. Allah menjadi manusia yaitu Yesus Kristus yang mengampuni dan menyelamatkan dengan menunjukkan jalan sebagai arah hidup yang benar bagi manusia lewat keseluruhan hidup-Nya. Dua hal dari banyak arah benar yang Yesus berikan bagi kita adalah makan secukupnya dan memiliki secara terbatas sebagai prinsip hidup sederhana yang berdimensi penyelamatan universal.Di era modern sekarang, kita diperhadapkan dengan realitas pola dan arah hidup manusia yang digerakkan oleh materialisme, konsumerisme dan hedonism makin hari makin memprihatinkan. Serba mudah, serba cepat, asal ada uang semua bisa dengan gampang diraih dengan kemajuan iptek, merupakan bahaya besar yang mendatangkan kehancuran bagi kehidupan semua makhluk bila manusia tidak sejalan dengan Yesus Kristus, sebab untuk memenuhi kebutuhan hidupnya, manusia menggerus kekayaan alam tanpa henti. Pola hidup Yesus merupakan kompas moral bagi manusia dan bila itu dipergunakan maka kabar baik menjadi milik segala makhluk.

Kata Kunci : Allah, Manusia, Segala Makhluk, Dosa, Injil, Syukur, Ketaatan, YesusKristus, Kesederhanaan.

\section{A. Latar Belakang Masalah}

Pada umumnya, saat orang Kristen mendengar kata Injil, yang terbersit dalam benak kita adalah hal-hal yang berkaitan dengan karya salib dan kebangkitan Yesus Kristus. Selanjutnya pokok ini segera dihubungkan dengan Perjanjian Baru (PB) sebagai kitab yang berbicara tentang keseluruhan hidup, pengajaran dan tindakan Yesus. Memang secara etimologi, kata Injil baru muncul dalam PB yaitu euaggelion yang berarti "kabar baik". Dan adalah benar juga karena makna Injil sebagai kabar baik mencapai puncaknya pada karya Yesus Kristus di salib dan kebangkitan-Nya. Namun yang menggelisahkan adalah hal ini lalu dipahami secara sempit bahwa penyelamatan Allah hanya ditujukan kepada manusia.Bila kita merunutnya dalam kerangka teologi, sebenarnya pemikiran seperti ini berkembang dari paradigma yang menempatkan manusia sebagai mahkota ciptaan sedangkan ciptaan lain dipandang sebagai obyek untuk memenuhi kebutuhan dan kepentingan manusia.Akibatnya muncul pemikiran bahwa karya keselamatan hanya diperuntukkan bagi manusia. 
Terkait dengan konsktruksi teologi di atas, kita dapat mengajukan pertanyaan kritis yaitu apakah Injil tidak terkandung dalam Perjanjian Lama (PL)? Apa makna Injil menurut PL? sejauhmana cakupan Injil dalam PL? Jika makna Injil adalah kabar baik bagi segala makhluk, mengapa pekerjaan Yesus dalam PB hanya bersentuhan dengan manusia saja?Semua pertanyaan tadi akan dibahas dalam tulisan ini sebagai upaya untuk menginterpretasikanInjil dalam PL secara khusus menurut teks Kejadian 7- 9 : 17 dan selanjutnya akan dipaparkan implikasinya bagi tanggung jawab manusia terhadap ciptaan lainnya. Interpretasi Injil menurut PL ini dapat mengayakan pemaknaan kita terhadap Injil dalam PB. Upaya ini sangat penting mengingat orientasi hidup manusia masa kini semakin dipengaruhi oleh nilai-nilai post-modern seperti materialisme, konsumerisme dan hedonisme. Ketiga paham ini semakin menempatkan manusia dengan segala kepentingan dan kesenangannya pada sentral kehidupan sehingga relasi yang terbangun dengan ciptaan lain adalah relasi instrumentalia. Pada gilirannya relasi seperti itu menyajikan wajah ciptaan lain yang compang-camping yang tentu saja bertentangan dengan makna Injil sebagai kabar baik bagi segala makhluk.

\section{B. Injil Dalam Narasi Kejadian 7-9:17}

Kejadian pasal 7-9:17 merupakan satu rangkaian cerita yang utuh. Diawali dengan turunnya hujan selama 40 hari empat puluh malam yang meluluhlantakkan segala bentuk kehidupan kecuali Nuh dan keluarganya serta seluruh makhluk hidup yang diperintahkan untuk masuk ke dalam bahtera yang telah dibuat berdasarkan perintah Tuhan. Bencana besar ini direncanakan Tuhan karena kejahatan manusia makin hari makin "akut". Penyakit ini dapat terdeteksi lewat hebatnya kerusakan dan kekerasan yang ditimbulkannya (Kej 6:5,11). Manusia yang pada awalnya adalah wakil Allah dalam mengelola dan mengusahakan bumi (Kej 1:28) sekarang menjadi perusak dan pelaku kekerasan. Menurut Emanuel Gerrit Singgih (selanjutnya EGS), kata 'rusak' (syakhat) dalam teks Kej. 6:11 dipakai dalam kaitan dengan tingkah laku segenap manusia. Demikian juga kata 'kekerasan' (khammas) menunjuk kepada tindakan dan kecenderungan niatmanusia yang telah rusak sehingga melulu menuju kepada kekerasan. ${ }^{1}$ 
Jadi di sini manusia adalah sumber dari kerusakan dan kekerasan tersebut.Dua penafsir kitab Kejadian yakni Walter Lampp dan EGS memberi makna terhadap dua kata tadi sebagai yang menunjuk kepada kejahatan terhadap sesama (aspek horisontal) dan terhadap Yang Ilahi (aspek vertikal). ${ }^{2}$ Kata “sesama”tidak saja menunjuk kepada manusia melainkan mencakup makhluk lain sebagai sesama ciptaan. Jadi aspek horizontal tidak saja berkaitan dengan manusia tetapi juga dengan ciptaan lain.Dengan begitu, kita telah melihat bagaimana manusia menjadi 'otak' dari kejahatan terhadap sesama dan terhadap Allah. Kenyataan itu membuat Allah bereaksi dengan mendatangkan penghancuran lewat air bah. Penghancuran itu tidak hanya ditanggung manusia melainkan juga segala makhluk. Namun penghancuran ini tidak boleh dipandang sebagai sesuatu yang negatif karena di dalamnya terkandung maksud lain yakni Allah hendak menciptakan kehidupan baru.

Di tengah zaman yang demikian rusak kondisinya akibat ulah manusia seperti di atas, terdapat kisah Nuh yang memelihara hidup dengan kualitasyang berbeda dari manusia pada masanya (Kej 6: 9), sehingga ia mendapat kasih karunia Tuhan. Allah menyatakan maksud baik-Nya bagi karya ciptaan-Nya. Maksud baik Allah itu diperlihatkan melalui kisah penyelamatan Nuh.Allah memerintahkan Nuh untuk membuat bahtera. Bahtera itu menjadi Bait Allah (kemah keselamatan menurut Pipi Agus Dhali) bagi Nuh bersama keluarga dan seluruh makhluk hidup yang dibawanya. Nuh dan keluarga serta binatangbinatang aman di dalam bahtera. Mereka selamat dari terjangan hujan dan air bah. Pasal tujuh diakhiri dengan kisah Nuh beserta seluruh isi bahtera mengapungapung selama 150 hari (Kej 7 : 24). ${ }^{3}$ Kenyataan ini patut mendapat perhatian secara khusus terkait dengan tindakan Allah, baik dalam menghukum maupun dalam menyelamatkan manusia dan binatang-binatang.Penghancuran memiliki dua kabar sekaligus yakni kabar buruk dan kabar baik. Kabar buruk karena semua kehidupan (yang buruk) dilenyapkan sedangkan kabar baiknya adalah orientasi manusia kepada kejahatan dan kekerasan dihentikan oleh Allah.Penting untuk kita catat bahwa penghukuman Allah berlaku bagi semua makhluk walaupun manusialah penyebabnya. 
Narasi selanjutnya adalah Kej 8:1-22 dimana narasi ini dimulai dengan tindakan Allah mengingat mereka yang di dalam bahtera. Tindakan mengingat tadi dilakukan Allah melalui dua cara yaitu : pertama, membuat angin berhembus melalui bumi, sehingga air itu turun, dan yang kedua, menutup mata-mata air samudera raya dan tingkap-tingkap langit supaya hujan berhenti (Kej 8:1,2). Dua cara ini dipakai Allah untuk mempersiapkan bumi yang layak huni bagi manusia dan seluruh makhluk di dalam bahtera. Makhluk lain seperti tumbuh-tumbuhan tidak disebutkan masuk bahtera bukan karena Allah tidak memberi perhatian terhadap mereka melainkan mereka akan hidup lagi seiring dengan keringnya air dari bumi. Tanah yang basah akan memunculkan tumbuhan baru. Kata mengingat(zakar) diartikanEGS dengan bukan sekedar mengingat, tetapi ingatan yang digerakkan oleh tujuan untuk menolong sepertiyang ditunjukkan dalam kisah Kej 30:22 dan Kel 2:24 dimana Allah bertindak menolong Rahel dan umat Israel. ${ }^{4}$ Yang mengalami pertolongan Allah dalam teks ini bukan hanya manusia tetapi Kej.8:1a mencatatnya demikian:maka Allah mengingat Nuh dan segala binatang liar dan segala ternak yang bersama-sama dengan dia dalam bahtera. Kalau kita memperhatikan teks ini maka kita mendapati pernyataan yang cukup jelas bahwa perhatian dan pertolongan Allah tidak hanya tertuju kepada Nuh dan keluarganya saja yang mewakili manusia tetapi juga makhluk lainnya. Hal lain yang perlu diperhatikan terkait dengan hal ini adalah relasi antara Nuh dan binatang-binatang yang dibawanya masuk ke dalam bahtera bukansebagaibahan makanan bagi Nuh melainkan supaya binatang-bintang ini dapat berkembang biak di bumi pasca air bah(Kej 6:20). Sebab saat mereka masuk bahtera, waktu itu masih berlaku pengaturan Allah yang pertama dengan Adam yaitu manusiahanya diperbolehkan makan tumbuhan saja. (Kej 1:29).Jadi tujuan memasukkan binatang dan hewan ke dalam bahtera mesti dipahami sebagai tindakan penyelamatan Allah terhadap ciptaan lain selain manusia. Manusia dan ciptaan lain mendapat perhatian dan pertolongan yang sama dari Allah.

Walau pun perhatian dan pertolongan Allah ditujukan kepada semua makhluk namun perlu diakui bahwa hanya manusia lah yang dapat mengungkapkan tanggapannya terhadap karya Allah melalui sikap moral. Nuh kemudian meneliti keadaan bumi setelah 40 hari (Kej 8:6).Dalam tindakan ini, 
Nuh melibatkan makhluk lain selain manusia yakni burung. Ia melepaskan seekor burung gagak yang kemudian terbang hilir mudik di atas air dan tidak kembali ke bahtera (Kej 8:7). Kemudian tiga kali Nuh melepaskan burung merpati untuk mengetahui apakah air telah benar-benar surut dari bumi. Kali pertama dan kedua, merpati belum memiliki tempat untuk hinggap sehingga ia kembali lagi ke bahtera (meskipun pada kali kedua sudah membawa sehelai daun zaitun). Baru pada kali ketiga merpati tidak kembali lagi ke bahtera sebagai tanda ia telah menemukan tanah yang kering sebagai tempat hidup dan itu artinya bumi telah kering (Kej 8:12-14). Kehidupan baru telah menanti Nuh dan keluarganya serta segala yang hidup dalam bahtera sesuai firman Allah.Inilah kabar baik dari Allah bagi Nuh dan seisi bahtera. Manusia dan ciptaan lain mendapat kesempatan yang sama. Kehidupan baru dimulai lagi bagi manusia dan juga untuk ciptaan lainnya.

Nuh merespon hal itu dengan mempersembahkan korban syukur kepada Allah (Kej 8:20).Respon ini pun melibatkan makhluk lain selain manusia yakni binatang yang diambil untuk dijadikan korban syukur (Kej. 8:20). Perbuatan syukur ini berkaitan dengan penyelamatan Allah yang telah diterima Nuh dan seisi bahtera.Jadi ada dimensi ucapan syukur atas perbuatan baik Allah yang hendak diutarakan. Menurut saya, hal ini baru memperlihatkan satu sisi saja dari korban syukur Nuh. Masih ada sisi lain yang perlu kita perhatikan lagi. Sisi lain yang saya maksudkan adalah kaitan antara korban syukur itu dengan perintah yang Nuh dan seisi bahtera lainnya terima dari Allah dalam Kej. 8:16,17. Dalam dua ayat ini terdapat perintah Allah kepada Nuh dan seisi bahtera untuk keluar dari bahtera demi keberlangsungan kehidupan baru. Perintah itu lagi-lagi tidak saja berkaitan dengan manusia tetapi juga untuk makhluk lainnya. Bagi Nuh dan keluarganya terdapat tanggung jawab yang kemudian dirinci dalam Kej 9:15.Mengapa saya mengaitkannya dengan hal ini? Karena narasi sebelum air bah memperlihatkan bagaimana kecenderungan manusia kepada hal yang jahat sangat intens. Hal itu terukur melalui pengabaian terhadap apa yang Allah perintahkan kepada manusia. Akibatnya dunia menjadi rusak. Tetapi sekarang setelah keluar dari bahtera, Nuh bertekad menunjukkan orientasi baru yakni taat kepada Allah yang diungkapkan melalui simbol korban syukurnya.Melalui tanda syukur ini Nuh menyatakan kesiapannya untuk tunduk kepada perintahAllah yang ia 
terima.Ketaatan untuk apa? Ketaatan untuk berpihak pada kehidupan. Ketaatan untuk berlaku baik dalam relasi horizontal dan vertikal, terhadap sesama (termasuk ciptaan lain) dan terhadap Allah.Pola penghayatan seperti ini kita temukan juga dalam dimensi persembahan dalam ibadah Kristen yaitu sebagai tanda syukur atas berkat Allah yang diterima melalui setiap peran dan usahahidup setiap hari. Dan juga sebagai simbol ketaatan umat untuk terlibat dalam misi Allah bagi kemaslahatan dunia.

Mandat yang Nuh terima sama dengan yang diberikan Allah kepada Adam dalam Kej 1:28-30 tetapi gagal dipenuhi oleh Adam dan keturunannya. Kegagalan ini telah membuat Allah menyesal telah menciptakan manusia sehingga bertekad untuk memusnahkan manusia(Kej. 6:5-7). Sekarang Nuh dengan komitmen tunduk kepada Allah yang disimbolkan oleh korban persembahan membuat perasaan Allah tergugahuntuk melakukan pembaharuan (re-creation). Tentu saya setuju dengan EGSbahwa ini bukanlah dalam pengertian menyogok Tuhan melainkan untuk menunjukkan Allah yang memiliki perasaan. ${ }^{5}$

Hal ini hendak mengungkapkan bahwa dalam perasaan-Nya Allah melihat kemungkinan untuk membaharui dunia sehingga Allah mengampuni (Kej $8: 21$ ), dan ini harus direspon dengan sikap ketaatan manusia. ${ }^{6}$ Allah merespon persembahan Nuh dengan menghapus kutukan terhadap tanah (Kej 8:21,22). Dari respon ini, saya ingin memperlihatkan hubungannya denganAdam dan keturunannya yang jatuh dalam dosa sehingga menyebabkan tanah terkutuk dan sekarang lewat respon ketaatan Nuh, tanah kembali dibebaskan dari kutuk.Oleh satu manusia (Adam) semua yang diciptakan kehilangan kepekaan akan cinta Tuhan, tetapi juga oleh ketaatan satu orang (Nuh) semua ciptaan kembali merasakan bagaimana rasanya dikasihi Allah. ${ }^{7}$

EGS menamakan Kejadian 8 sebagai ungkapan cinta Tuhan terhadap dunia, ${ }^{8}$ dan ini menginsipirasi saya untuk menamakan persembahan Nuh sebagai mawar cinta untuk bumi dan segala makhluk. Biasanya orang yang sedang jatuh cinta membawakan bunga untuk sang kekasih sebagai tanda cinta. Dan kebanyakan memilih bunga mawar sebagai simbol cinta itu. Melalui imajinasi, saya membayangkan Nuh dengan wajah yang berhiaskan kegembiraan mendatangi Allah. Kegembiraan itu karena Allah mencintai Nuh, keluarganya dan 
seluruh makhluk lainnya. Nuh memberikan mawar cinta itu kepada Allah. Uniknya mawar cinta ini tidak langsung diserahkan kepada sang 'kekasih' (bumi dan segala makhluk) tetapi diserahkan kepada Allah. Mengapa? Nuh menempatkan Allah menjadi saksi atas sumpah setianya untuk mencintai bumi dan segala makhluk sebagaimana ia mencintai dirinya sendiri. Mawar cinta itu adalah wujud komitmen manusia untuk bertanggung jawab atas kelangsungan hidup ciptaan lain.Kecintaan terhadap bumi dan segala makhluk terlihat dalam upaya manusia untuk mengembangkan kehidupan yang memperhatikan dimensi kebersamaan. Manusia tidak boleh membangun hubungan yang menempatkan makhluk lain sekedar sebagai instrumen bagi hidupnya. Manusia adalah mezbah cinta kasih Allah bagi ciptaan lain sehingga kelestariannya perlu diperhatikan. Di dalam cinta, keharmonisan akan tercipta apabila seseorang memandang pasangannya sebagai keberadaan yang membuat hidupnya sangat berarti dan bukan sebagai obyek untuk memuaskan keinginan.Untuk itu tepatlah apa yang dikemukakan Adrianus Sunarko yang menyebutkan bahwa ciptaan lain harus dipandang sebagai saudara dan saudari kita. ${ }^{9}$

Tanda cinta Allah bagi segala makhluk dikemukakan lagi dalam narasi Kej 9:9-17 dalam bentuk perjanjian yang dimeteraikan dengan pelangi. Janji Allah untuk tidak lagi menghukum bumi dan segala yang hidup dengan air bah mendapat legitimasi hukum dengan pelangi sebagai meterainya. Lagi-lagi pelangi tidak hanya merupakan tanda bagi manusia tetapi juga tanda bagi segala makhluk tetapi sudah tentu hanya manusia yang dapat menangkap makna meterai ini. Kemampuan manusia dalam menangkap makna meterai janji Allah ini kembali lagi harus dilihat sebagai mawar cinta untuk bumi dan segala yang hidup seperti yang telah saya kemukakan di atas.

Dalam narasi Kej 7-9:17Injil sebagai kabar baik memiliki dua sisi yaitu penghancuran di satu sisi sebagai bentuk pengamputasian kejahatan dan pada sisi yang lainnya penghargaan terhadap ketaatan. Penyelamatan Allah terhadap Nuh dan keluarganya memang mudah ditafsirkan secara sempit bahwa hanya manusia yang mendapat karunia sotereologi. Kita hanya melihat manusianya dan lupa memberi perhatian bahwa di dalam bahtera itu juga ada binatang-binatang. Namun setelah membaca narasi Kej 7-9:17 secara cermat, kita ditolong untuk 
menggemboskan pikiran demikian karena dua kenyataan. Kenyataan pertama adalah manusia 'otak' kejahatan dan kekerasan yang menyebabkan lenyapnya seluruh kehidupan. Makna Injil sebagai kabar baik dalam kenyataan ini nampak dalam bentuk yang tidak selalu sesuai dengan definisi kebanyakan orang mengenai kabar baik. Lazimnya menurut kita kabar baik adalah sesuatu yang menggembirakan, selalu dalam bentuk yang baik dan positif. Tetapi kita mesti juga terbuka bahwa ada unsur relatif. Kabar baik tergantung siapa dan situasi apa yang sedang terjadi. Ambil contoh, kalau seorang pelaku pembunuhan sedang dipukuli warga dan kemudian polisi datang menghentikannya maka itu merupakan kabar baik baginya. Tetapi bagaimana kalau seorang dokter yang sedang melakukan amputasi kaki bagi pasien diabetes akut lalu dihentikan. Apakah tindakan itu merupakan kabar baik? Sudah tentu tidak. Mengapa? Kedua keadaan itu memiliki tujuan yang berbeda. Pada kasus pertama tindakan menghentikan pemukulan yang dilakukan warga merupakan penyelamatan terhadap si pelaku. Sedangkan dalam kasus kedua tindakan menghentikan amputasi justru menyebabkan kematian bagi pasien tersebut. Analogiini menolong kita untuk memahami peristiwa air bah dalam narasi tadi.Kenyataan yang kedua, Nuh yang mempertahankan hidup saleh menjadi 'pelindung' bagi makhluk hidup yang diperintahkan Allah untuk dibawanya masuk ke dalam bahtera. Selanjutnya Nuh diberikan tanggung jawab untuk menata dunia pasca air bah. Penataan ini sudah tentu tidak saja berlaku untuk kehidupan manusia tetapi juga bagi segala makhluk lainnya.Keberlangsungan hidup manusia sangat ditentukan oleh keberadaan ciptaan lain. Pada posisi ini, Nuh memiliki peran sebagai co-creator yang meneruskan ungkapan cinta Tuhan kepada segala makhluk. Bagi Allah, betapapun kejahatan manusia telah begitu merusak segala yang "sungguh amat baik" dalam pandangan-Nya tetapi pada prinsipnya ciptaan itu baik adanya. Hal ini membuat Allah berkomitmen membangun kembali dunia ciptaan-Nya melalui manusia. ${ }^{10}$

Tanggung jawab penataan itu disertai jaminan janji Allah yang tujuannya bukan monopoli manusia melainkan anugerah bagi segenap ciptaan. Peran manusia sebagai co-creator dipandang Allah sebagai something dan bukan 
everything.Peran manusia penting tetapi manusia bukanlah segala-galanya dan karena itu dia bukanlah fokus tunggal dari kabar baik Allah.

Sampai sejauh ini kita telah diajak untuk menyelami kabar baik Allah sebagai Injil bagi segala makhluk yang terkandung dalam PL secara khusus dalam narasi Kej. 7 - 9. Kabar baik itu terwujud dalam tindakan-tindakan Allah baik berupa penghukuman, penyelamatan, perjanjiandan perintah yang cakupannya tidak hanya terbatas kepada manusia melainkan meliputi seluruh makhluk. Manusia dan makhluk lainnya memiliki empat kesamaan dalam terminologi narasi Kejadian 7 - 9 yakni sama-sama mengalami penghukuman, sama-sama diselamatkan, sama-sama menerima perintah dan yang terakhir sama-sama menerima perjanjian Tuhan. Yang membedakan manusia dengan makhluk lain adalah kenyataan bahwa dialah penyebab kerusakan dan yang mendatangkan hukuman dan dialah pula yang dapat merespon secara moral perintah dan janji keselamatan Tuhan. Berangkat dari kenyataan ini maka tujuan dari kabar baik itu adalah agar manusia dan segala makhluk dapat melestarikan dan menjaga kekonstanan kehidupan yang dikaruniakan Allah kepada mereka.

Jika demikian makna Injil dalam PL maka pertanyaan selanjutnya adalah bagaimana korelasi antara Injil yang terkandung dalam narasi Kejadian ini dengan makna Injil dalam PB yang puncaknya terlihat dalam seluruh hidup dan karya Yesus yang nampaknya memberi perhatian pada manusia saja? Pertanyaan ini menjadi pokok yang akan kita bahas pada bagian berikut dengan fokus pada hidup dan karya Yesus menurut iman Kristen.

\section{Cakupan Injil Dalam Karya Yesus.}

Hidup dan karya Yesus merupakan puncak Injil dalam PB. Namun dalam kenyataannya menurut kesaksian PB, pelayanan Yesus bersentuhan langsung dengan manusia. Simak saja bagaimana Yesus menyembuhkan si kusta, yang buta, si timpang, si lumpuh, yang kerasukan setan, yang sakit pendarahan dan seterusnya. Lihat juga bagaimana Yesus memberi makan empat ribu atau lima ribu orang yang kelaparan, mengampuni perempuan yang kedapatan berzinah, memberkati anak-anak, bahkan membangkitkan orang mati. Semuanya 
berhubungan dengan manusia dan sangat jarang memunculkan kisah tentang bagaimana Yesus menyelamatkan ciptaan lain.

Kesaksian PB yang demikian memunculkan pertanyaanmengapa pekerjaan-Nya seolah-olah hanya berkaitan dengan manusia saja dan kurang bersentuhan dengan makhluk lainnya? Pertanyaan ini akan dibahas dalam rangka menemukan benang merah kedudukan manusia dalam tanggung jawabnya terhadap ciptaan lain, sehingga cakupan Injil dalam PB dapat diperlihatkan. Sudah tentu saya tidak sedang bergerak ke kutub penekanan berlebihan kepada kemanusiaan Yesus sebagai lawan dari kutub yang menekankan keilahian Yesus secara berlebihan seperti yang terjadi dalam kenyataan berteologi selama ini. Nasehat EGS mengenai hal itu, ${ }^{11}$ saya jadikan tanda awas untuk menjaga keseimbangan penekanan dalam pembahasan topik ini. Penekanan secara berat sebelah pada salah satu model penghayatan iman akan siapa Yesus (Kristologi yang menekan keilahian dan kemanusiaan Yesus) menurut Banawiratma hanya akan memperkurus kesaksian Alkitab tentang Yesus, karena itu keduanya mesti saling melengkapi. ${ }^{12}$

Dalam credo iman Kristen,Kekristenan mengakui bahwa Yesus adalah Allah yang datang sebagai manusia. Tepatnya pengakuan ini dirumuskan demikain oleh G.C. van Niftrik dan B.J. Boland: "Pada satu pihak Yesus sama sekali tergolong kepada Allah dan pada pihak lain, Ia sama sekali tergolong kepada kita manusia". ${ }^{13}$ Dari pihak Allah, Ia datang menjumpai manusia di dalam Yesus dan dari pihak manusia, di dalam Yesus dia berjumpa dengan Allah. ${ }^{14}$ Mengenai hal ini sudah banyak pandangan para teolog yang sudah menjadi dasar dari pengajaran gereja.Tetapi dengan menggunakan narasi Kej 79:17 yang tidak terlepas dari Kej 1-11 secara menyeluruh, saya akan memberi perhatian kepada credo iman tadi untuk memperlihatkanhubungan antara kenyataan kegagalan sang manusia sebagai co-creator yaitu Nuh dan keturunannya pada satu pihak dan terhadap komitmen Allah untuk never again pada pihak lainnya.

Pada bagian sebelumnya, saya telah membahas bagaimana Nuh dan keturunannya menjadi co-creator setelah Adam dan keturunannya dilenyapkan dengan air bah karena kecenderungan hatinya terhadap kejahatan dan kekerasan 
terhadap Allah dan sesama. Itulah narasi Kej 7-9:17, namun kisah itu ternyata tidak berhenti. Keturunan Nuh ternyata juga kembali pada kecenderungan kejahatan seperti manusia sebelumnya. Hal ini dapat kita temukan dalam narasi Kej 9:18-29 sampai berlanjut kepada kisah menara Babel dalam pasal 11. Mawar cinta yang dipersembahkan Nuh ternyata keharumannya mulai terkikis dalam perjalanan waktu ketika keturunannya terus berkembang. Apabila kejahatan itu makin meningkat melebihi batas kesabaran Allah, Ia akan turun tangan.Tetapi tidak dengan maksud negatif melainkan mengamputasi sehingga kehidupan dapat terus berlangsung. Sepanjang kisah PL baik yang dimulai dari Adam kemudian Nuh, Abraham, Israel (bangsa dimana Allah mengikat diri-Nya dengan mereka) kita melihat liukkan kerapuhan, ketidaktaatan, kejahatan, kekerasan, perlawanan manusia dan kemarahan serta kemurahan Yang ilahi nampak dalam warna yang sangat mencolok. Kadang Allah nampak seperti orang tua yang merangkul, membimbing dan mengasihi anaknya tetapi tidak jarang juga Allah harus berdiri sebagai penantang, hakim dan polisi yang menindak dengan tegas manusia dalam kejahatannya. Hukuman pun kerap kali harus dijatuhkan baik berupa penyakit, kelaparan, dijarah dan dikuasai bangsa lain sampai kepada pembuangan ke negeri asing (Babel dan Asyur). Kitab akhir dalam PL yaitu Maleakhi disebut sebagai nabi terakhir yang Tuhan pakai untuk menyampaikan penghukuman dan kasihNya bagi Israel. Setelah itu kira-kira 400 tahun, Allah berdiam diri terhadap perilaku manusia. Manusia dan Allah tidak "sejalan”lagi.

Tetapi apakah itu berarti Allah tidak mengingat manusia lagi? Ternyata tidak! Kita kembali berjumpa dengan Allah yang telah bertekad untuk come to terms terhadap kerapuhan manusia yang demikian. ${ }^{15}$ Itulah sebabnya Allah datang sebagai manusia. Dia adalah Yesus Kristus. Sampai di sini pertanyaan mengenai siapa Yesus menurut iman Kristen kiranya jelas sudah. Yesus adalah cara berada Allah yang kedua yaitu sebagai manusia yang merupakan kelanjutan dari karyaNya yang tidakmungkin dapat dibatalkan oleh kejahatan dan kekerasan manusia. Komitmen Allah untuk never again terus diperlihatkan dan ini merupakan anugerah bagi keberlangsungan kehidupan manusia dan dunia. Ia harus menjadi manusia karena manusia yang Ia ciptakan kehilangan arah, tersesat dan tidak tahu jalan pulang.Kita dapat membandingkan ungkapan ini dengan pernyataan Yesus 
yang dicatat dalam Injil Yohanes 14:6 bahwa Ia adalah jalan dan kebenaran dan hidup. Adam, Nuh, Abraham, Ishak, Yakub, Israel, singkatnya semua manusia telah berdosa dan kehilangan kemuliaan Allah kata Paulus (Roma 3:23).Dengan tetap setia terhadap definisi dosa menurut narasi Kejadian, yaitu kejahatan terhadap Allah (vertikal) dan terhadap sesama-termasuk ciptaan lain (horisontal), maka akibat dosa sudah pasti tidak hanya dialami manusia saja melainkan oleh segala makhluk ( $\mathrm{Rm}$ 8:22). Pola yang sama berlaku ketika Allah datang sebagai manusia yaitu Yesus yang come to terms dengan manusia. Karya Yesus menjadi mawar cinta untuk manusia dan segala makhluk lainnya. Jika Nuh mempersembahkan korban dengan makna ganda yaitu syukur dan ketaatan yang saya sebut sebagai mawar cinta, maka Yesus sang Manusia mempersembahkan mawar cinta dengan korban yaitu diri-Nya dan ketaatan. Keduanyanyata dalam seluruh karya Yesus sampai pada kayu salibyang berfungsi sebagai "pelangi" atau meterai kehidupan baru (I Kor 11:25) bagi segala makhluk.Melalui mawar cinta ini, Allah dan manusia "sejalan"lagi. Harapan baru terbuka lagi bagi manusia yaitu ditemukannya“jalan"pulang ke dalam persekutuan dengan Allah, dan dengan demikian kehidupan layak diteruskan. Teologi never again kembali didendangkan Allah untuk manusia melalui Sang Manusia. Bukankah ini recreation lagi?

Memang harus diakui bahwa pelayanan Yesus sebagai Juruselamat dalam keseluruhan Kitab Injil berpusat kepada manusia. Namun dengan merujuk kepada pembahasan mengenai Yesus sebagai Allah yang menjadi manusia di atas, kita dapat bergeser dari pemahaman yang melulu memandang keselamatan hanya untuk manusia semata. Dalam karya keselamatan Yesus, manusia ditempatkan secara "terbuka"sedangkan makhluk lain "tersembunyi". Mengapa demikian? Saya kembali pada pola yang kita sudah lihat dalam narasi Kejadian, yaitu pertama, pemulihan terhadap manusia memilikidampak bagi seluruh makhluk sebagaimana dosanya menyebabkan semua kehidupan lenyap. Kedua, manusia memiliki kemampuan untuk merespon meterai janji Allah dengan ketaatan yang tentu wujudnya adalahpengembangan kehidupan bersama segala makhluk menurut jalan yang Yesus tunjukan. Itulah sebabnya dalam Amanat Yesus kepada para murid-Nya untuk tugas pemberitaan Injil menurut versi Markus, segala 
makhluk mendapat tempat yang sama yaitu sebagai sasaran atau penerima Injil (Mark 16:15).

\section{Paradigma Baru di Era Baru}

Bagian ini saya awali dengan pertanyaan mengapa Yesus memilih dilahirkan sebagai manusia sederhana? Apakah Allah kekurangan orang kaya, pejabat dan kaum ningrat pada masa itu sehingga Ia menjatuhkan pilihan pada si Yusuf tukang kayu?. Pertanyaan ini penting karena terkait dengan pemaknaan manusia terhadap never again Sang Manusia dan sekaligus merupakan perwujudan dari kesetiaanuntuk menempuh“jalan”pulang yang telah ditunjukkan Sang Manusia sehingga peran manusia sebagai co-creator dapat terus berjalan. Paradigma baru dibutuhkan ketika manusia hidup di masa yang menawarkan begitu banyak kemudahan sebagai konsekuensi dari kemajuan yang dicapai. Pada era baru ini manusia diperhadapkan dengan berbagai kenyataan dimana perubahan begitu kuat mempengaruhi dan mengubah nilai dan orientasi hidupnya.

Dalam kitab Injil kita membaca bahwa Yesus dilahirkan dalam keluarga Yusuf dan Maria yang sehari-hari melakukan pekerjaan sebagai tukang kayu. Pada masa itu, dari pekerjaannya saja seseorang sudah dapat digolongkan ke dalam tingkatan miskin, menengah atau kaya. Pekerjaan tukang kayu identik dengan miskin. Masih ada fakta lain lagi yang bisa kita ajukan yaitu pada saat Yesus dibawa ke Bait Allah untuk diserahkan sesuai ketentuan Taurat, Yususf dan Maria hanya mampu membawa persembahan berupa sepasang burung tekukur atau dua ekor anak burung merpati (Luk 2:24). Persembahan ini sesuai Imamat12:8 sebagai alternatif jika tidak mampu membawa seekor kambing atau domba. Lalu muncul pertanyaan, apakah ini nasib seperti terjadi pada manusia mana pun yang tidak dapat meminta untuk dilahirkan dalam keluarga dengan status sosial tertentu?. Ataukah memang disengajakan dengan maksud tertentu? Saya bertolak dari Pengakuan Iman Rasuli yang menyatakan bahwa Yesus lahir sebagai karya Roh Kudus maka jawabannya pada hemat saya adalah tindakan yang disengajakan oleh Allah sendiri. Secara sadar Allah memilih "cara berada"yang kedua ini sebagai manusia miskin. Sudah tentu bukan karena pada waktu itu tidak ada pejabat, yang kaya dan keturunan ningrat sebagai "tempat bagi 
cara beradanya"Allah melainkan kesadaran akan apa yang akan Ia sampaikan dengan "cara berada"tersebut.

Nilai-nilai yang dihidupi oleh seseorang sangat dipengaruhi oleh keadaandi sekitarnya.Nilai-nilai itu akan muncul dalam perilaku dan gaya hidup seseorang dalam kesehariannya. ${ }^{16}$ Saya sebutkan contoh, Jokowi yang berlatarbelakang kesederhanaan dalam penampilannya selalu sederhana walaupun ia berada dalam kedudukan sebagai pejabat, baik sebagai orang nomor satu di DKI Jakarta pada waktu lampau maupun sekarang telah dilantik menjadi orang nomor satu di Republik ini. Kesederhanaan itu nampak antara lain dalam cara berbusananya yang tidak tiba-tiba berjas kemana-mana. Walaupun saya tidak menutup mata terhadap ada juga kenyataan dimana orang sederhana yang kemudian berduit tidak mau sederhana lagi dengan prinsip sudah "kenyang"dengan kesederhanaan yang menurutnya identik dengan penderitaan dan kemiskinan.Atau kenyataan lain lagi yaitu orang "sederhana"yang tidak sederhana. Seperti trend anak muda pengguna jeans yang penuh dengan sobekan di sekitar lutut tetapi kalau ditelusuri harga jeansnya dibandrol dengan harga yang cukup mahal. Tentu saja harus dibedakan antara kemiskinan dan kesederhanaan walaupun kadang-kadang keduanya nampak secara berdampingan. Kamus Besar Bahasa Indonesia memberi arti kata "sederhana"demikian : "bersahaja, tidak berlebih-lebihan", sedangkan kata "miskin"artinya : tidak berharta; serba kekurangan atau berpenghasilan rendah". ${ }^{17}$ Dalam pengertian kata sederhana, terkandung kemungkinan bahwa seseorang bisa saja memiliki sesuatu berupa uang, barang, pengetahuan, ketrampilan atau kepemilikan lainnya tetapi tidak dipergunakan secara berlebihan. Sedangkan dalam pengertian kata miskin, kemungkinan itu tidak ada karena memang keadaannya serba berkekurangan atau berpenghasilan rendah. Kesederhanaan merupakan gaya hidup yang mesti diupayakan sedangkan kemiskinanadalah suatu kenyataan yang perlu diperjuangkan untuk diatasi.

Kesederhanaan sebagai sebuah lifestyle sangat jelas diperlihatkan Yesus dalam kehidupan sehari-hari dan hal itu dapat kita telusuri dalam hal-hal praktis yang bersentuhan dengan kehidupan-Nya seperti makanan, pakaian, rumah dan kendaraan yang dipergunakan dalam pelayanan-Nya. Untuk menjelaskan hal ini, 
saya mengandalkan informasi dari $\mathrm{T}$. Tri Harmaji. Ia memberi informasi mengenai kehidupan sehari-hari Yesus sebagai manusia sesuai dengan tujuan penulisanya. Saya menggunakan informasi tersebut untuk menunjukkan “jalan”pulang atau way of life yang diajarkan Sang Manusia terkait dengan pokok tulisan yaitu gaya hidup Sang Manusia yang berdampak terhadap ciptaan lain selain manusia.

Saya telah mengemukakan bahwa Yesus adalah Allah yang kembali menunjukkan never again kepada manusia dengan jalan menjadi manusia.Never again bukanlah pengharapan yang membuat manusia hidup semau gue melainkan dorongan untuk bertindak sebagai co-creator dan menanti-nantikan Tuhan setiap waktu. Melalui gaya hidup sederhana Yesus, manusia memperoleh teladan sebagai kompas agar tidak tersesat dalam rimba kehidupan. Beriman kepada Yesus berarti bersedia menjadikan gaya hidup-Nya sebagai gaya hidup kita. Kita tidak hanya sibuk mempelajari ajaran dan kisah hidup-Nya saja lalu alpa menghayatinya dalam kehidupan nyata. ${ }^{18}$ Belajar tentang Yesus tanpa melahirkan sebuah kehidupan baru,seumpama baru beradapada tahap membaca petunjuk tentang kompas saja dan belum menggunakannya.

Yesus hidup sebagai bagian dari masyarakat Yahudi dengan tradisi, adatistiadat dan gaya hidup tertentu. Cara Yesus berbicara, berpakaian, makan, berpergian, merupakan produk gaya Yahudi tetapi Ia memiliki nilai tersendiri yang melahirkan lifestyle-Nya sendiri. Mengapa? Yesus bertumbuh dalam keluarga sederhana. Nilai-nilai kesederhanaan yang terinternalisasi dalam diri Yesus tidak datang begitu saja karena Ia adalah Allah, melainkan tumbuh dan berkembang dalam proses kehidupan-Nya. Tiga puluh tahun dari masa hidup sebelum Ia berkarya memang tidak terekam dalam Alkitab. Tetapi Luk 2:51,52 memberi sedikit petunjuk bagi kita bahwa Yesus bertumbuh dalam pengasuhan Yusuf dan Maria dengan kualitas hidup yang sangat baik di hadapan Allah dan manusia. Di sana, Yesus berinteraksi dengan masyarakat Yahudi dan Ia belajar untuk menyisihkan berbagai nilai untuk menemukan dan menetapkan nilai seperti apa yang Ia hidupi. Nilai itulah yang mewujud dalam gaya hidup Yesus. Kita dapat menemukan banyak contoh dari prinsip kesederhanaan Yesus dalam Alkitab, 
namun saya hanya akan meneropong dua saja dari prinsip tersebut yaitu, mengkonsumsi secukupnya dan memiliki secara tak berkelebihan. ${ }^{19}$

Salah satu contoh dari kemanusiaan Yesus yang dicatat oleh Alkitab adalah merasa lapar (Mat 4:2) dan haus (Yoh 19:28). Dia butuh makan dan minum. Sudah tentu tidak ada jenis makanan "ilahi”untuk Yesus. Ia makan dan minum yang biasa dinikmati oleh orang Yahudi tetapi pilihan untuk makan apa saja itu berpulang kepada pribadi Yesus sendiri.Mengenai gaya hidup soal makan dan minum ini dapat kita gali dari pengajaran-Nya tentang "Doa Bapa Kami”. Yesus mengajarkan para murid-Nya untuk meminta kepada Bapa makanan yang secukupnya. Kata "secukupnya"memiliki pengertian makan dan minum punya batas. Tidak lebih dan tidak kurang, tapi cukup. Ditambah lagi dengan keterangan sebelumnya yaitu "pada hari ini". Jadi berarti makanannya sudah secukupnya untuk hari itu. Bukan cukup untuk dua hari, satu bulan, satu tahun, apalagi kalau sampai cukup dimakan tujuh turunan. Pengajaran mengenai doa ini Yesus sampaikan untuk mengajarkan kepada para murid-Nya melepaskan diri dari rasa kuatir yang berlebihan karena Bapa memberi kecukupan setiap hari.Kekuatiran yang berlebihan akan menyebabkan timbulnya keserakahan, karena itu dengan pengajaran ini Yesus mencegah manusia dari keserakahan dengan segala dampaknya baik terhadap sesama maupun terhadap sumber daya alam.

Pada masa di mana Yesus hidup, Ia berkesempatan memiliki banyak barang mengingat popularitasnya begitu memikat banyak orang baik di kalangan rakyat jelata, menengah sampai kepada kelas pejabat.Pengajaran-pengajaran-Nya mendatangkan decak kagum luar biasa dari para pendengar-Nya bahkan mereka dapat merasakan bahwa khotbah-khotbah Yesus memiliki power tersendiri. Apalagi ketika Yesus melakukan mujizat dalam kondisi tertentu, makin hebatlah kedudukan Yesus dibandingkan para rabi lainnya. Tetapi justeru di tengah ketenaran itu, Yesus malah memilih untuk memiliki barang dalam jumlah seadanya. Terkait dengan hal ini, kita dapat melihat prinsip tadi nyata dalam kehidupan Yesus. Ia tidak mempunyai uang yang cukup untuk membiayai kebutuhan pelayanan-Nya sehingga beberapa perempuan tergerak untuk memberi sumbangan sukarela (Luk 8:1-3). Contoh lain dapat kita temukan dalam apa yang Yesus sampaikan sebagai jawaban atas pertanyaan yang diajukan orang muda 
dalam Luk 12:13-21. Menurut Harmaji, orang muda ini disebut sebagai orang bodoh oleh Yesus bukan karena ia mengumpulkan banyak harta tetapi orientasi hidupnya yang sangat egosentris. ${ }^{20}$

Saat Yesus meminta kesediaannya untuk menjual segala harta miliknya dan dibagikan kepada sesama, ia tidak bisa karena itu ia meninggalkan Yesus dan mengikuti jalannya sendiri. Bagi Yesus kedudukan, ketenaran dan nilai diri tidak diukur berdasarkan kepemilikan barang-barang tertentu tetapi pada kenyataan bahwa hidup bisa menjadi mezbah cinta bagi sesama. Ketika manusia berpusat pada dirinya sendiri dengan memanfaatkan segala yang ada hanya untuk diri sendiri atau kalangan sendiri, maka ia tidak berada di "jalan” yang sama dengan Allah atau lebih tepatnya "tersesat".

Dua prinsip yang menjadi sumber dari dari gaya hidup Yesus di atas akan kita pakai untuk melihat bagaimana pola hidup manusia pada masa sekarang. Dunia sekarang ini telah memasuki masa yang disebut sebagai era modern. Manusia mengalami kemajuan yang luar biasa pesat berkat kemajuan ilmu pengetahuan dan teknologi. Industri menjadi begitu kuat mempengaruhi berbagai bidang kehidupan. Berbagai dampak positif dari kemajuan ini kita nikmati seperti mudah mengakses informasi, mudah bepergian, mudah berkomunikasi, pendidikan makin maju, penemuan-penemuan di bidang kedokteran yang sanagt menolong dan berbagai kemudahan lainnya. Berbagai produk ditawarkan mulai dari peralatan rumah tangga, alat dan bahan kecantikan, model pakaian, perhiasan, alat komunikasi, alat transportasi berkekuatan jet, 'games' seru bahkansampai kepada makanan siap saji dengan tingkat kemudahan yang luar biasa. Manusia tidak diharuskan berlelah-lelah untuk memperoleh apa yang diinginkannya asal ada uang. Pada era ini, kekuatan ilmu pengetahuan dan teknologi, industri dan pertumbuhan ekonomi tak terbatas menjadi tiga utas tali yang terjalin satu dengan yang lainnya sehingga menghasilkan kekuatan luar biasa.

Kemajuan mempermudah manusia memenuhi kebutuhannya, seperti sandang, pangan, papan, pendidikan dan kesehatan demi kelangsungan hidup. Namun kemajuan itu juga mempengaruhi pola hidup manusia.Nilai-nilai seperti materialisme, konsumerisme dan hedonisme tidak sulit untuk ditemukan dalam hidup manusia zaman ini. Orang mengukur tingkat kemakmuran dan kesuksesan 
berdasarkan berapa besar tingkat pendapatan, banyaknya kepemilikan barang seperti barang-barang bermerk atau yang lagi trend. Orientasi manusia berubah. Kalau dulu orientasi manusia untuk berjuang memenuhi kebutuhannya supaya hidup maka pada masa sekarang, kebutuhan berubah menjadi penentu nilai diri, prestasi dan prestise. ${ }^{21}$ Alhasil terbentuklah nilai dan perilaku meraup atau mengumpulkan sebanyak-banyaknya, cari yang gampang, praktis dan cepat, mudah tergiur yang baru, merasa tidak hidup kalau tidak memiliki sesuatu yang mahal, merasa rendah diri dan ketinggalan zaman jika pakaian, makanan, dan penampilan tidak mengikuti trend yang lagi beredar. ${ }^{22}$ Lalu apa kaitan semua ini dengan ciptaan lain? Albert Nolan menyatakan bahwa ketamakan manusia pada masa ini merupakan penyebab kepunahan ciptaan dan kerusakan bumi. ${ }^{23}$

Pada dasarnya memenuhi kebutuhan bukanlah hal yang bertentangan dengan pesan Alkitab. Dalam narasi Kej 9:3,4Allah menjamin kebutuhan Nuh dan keluarganya dengan menetapkan bahan makanan baginya yang diambil dari ciptaan lain tetapi tetap ada batasnya. Jelaslah bagi kita hubungan antara pemenuhan kebutuhan manusia merupakan kesatuan yang tidak terpisahkan dengan ciptaan lain sebagai sumbernya. Untuk makan, manusia butuh tumbuhtumbuhan seperti padi, jagung, ubi-ubian, air, ikan, ayam, sayuran dan seterusnya. Kebutuhan pakaian diperoleh dari olahan kapas atau tumbuhan lainnya. Bahkan untuk membawa dan mengolah bahan-bahan tadi, manusia tetap bergantung pada benda lain lagi seperti karung, kantung plastik, periuk, kuali dan seterusnya. Contoh lain lagi, untuk memenuhi kebutuhan papan, manusia memerlukan batu, kayu, seng, paku, semen, pasir dan seterusnya. Semuanya dari ciptaan lain. Makin besar kebutuhan manusia, makin banyak sumber alam (ciptaan lain) yang diambil untuk memenuhinya. Makin sering manusia menggunakan barang-barang tadi, makin banyak bahan yang dibutuhkan untuk diproduksi lagi, lagi dan lagi.Kecenderungan untuk makin memenuhi kebutuhan pembangunan dan pertumbuhan ekonomi menyebabkan manusia merusak lingkungan hidup. ${ }^{24}$

Eksploitasi secara tak bertanggung jawab terus terjadi dan di sinilah pentingnya manusia melakukan pembalikan arah. Menekan keserakahan dan berjalan pada “jalan"kesederhanaan seperti gaya hidup Sang Manusia. Kesederhanaan, tidak berlebihan atau bersahaja memberi ruang kepada ciptaan 
lain untuk mengembangkan diri dan mengalami yobel demi kelestariannya.Kita dapat menyebut upaya reboisasi, penghematan penggunaan sumber daya alam, pengolahan tanah yang tidak berlangsung terus-menerus, pemilihan pupuk organik, penggunaan barang-barang produksi secara terbatas, pemanfaatan alat transportasi secara proporsional, buang sampah pada tempatnya dan perlakuan yang bertanggung jawab terhadap makhluk hidup lainnya, sebagai upaya pembalikan arah seperti yang telah dikatakan sebelumnya.Seruan Paus Yohanes Paulus II agar manusia jangan menjadi serigala bagi ciptaan lain (homo homini lupus), merupakan hal penting yang harus segera diperhatikan manusia. Seruan itu lahir dari penghayatan akan kedudukan manusia sebagai co-creator $^{25}$ dimana kedudukan ini telah mendapat pemulihan dalam Yesus Sang Manusia.

Tumbuhnya nilai-nilai hidup seperti materialisme, konsumerisme dan hedonisme berawal dari konsep nilai diri manusia yang keliru arah. Manusia menempatkan dirinya sebagai everything padahal sejak Adam sampai kepada Nuh dalam narasi Kejadian, manusia adalah something di tangan Allah dan juga dalam relasi dengan ciptaan lain. Prinsip ini telah dikembangkan oleh Yesus. Di dalam gaya hidup kesederhanaan Yesus, manusia dikembalikan pada jalan yang benar. Manusia sudah terlampau sibuk dengan dirinya sendiri sehingga ia lupa pada pelangi yang jauh di langit sana tetapi Pelangi yang di langit itu telah begitu dekat dengan kehidupan manusia yaitu Sang Manusia yang adalah Firman menurut Injil Yohanes.Sebagai umat kristiani, Firman itu begitu sering kita pelajari tetapi belum begitu nyata dalam perilaku kita. Tetapi bagaimana pun keadaan kita, itulah kabar baik bagi manusia yang kehilangan arah, dan serempak dengan kembalinya manusia ke jalanyang benar, dalam ketaatan yang tulus, makhluk lain pun menerima "Injil".

\section{Penutup}

Menyimak pengulasan mengenai makna dan cakupan Injil baik dalam PL maupun dalam $\mathrm{PB}$, kita mendapati bahwa pemikiran yang menyatakan bahwa keselamatan hanya ditujukan kepada manusia merupakan pereduksian kesaksian Alkitab. Cakupan Injil adalah meliputi seluruh ciptaan Allah. 
Pereduksian ini telah membawa pengaruh yang berbahaya bagi kekonstanan hidup ciptaan Allah yang ditunjukkan dalam sikap dan pola hidup manusia terhadap ciptaan lain. Pola relasi subyek - obyek yang dibangun manusia berhadapan dengan ciptaan lainnya merupakan cerminan dari 'salah arah' yang bersumber pada pereduksian makna tadi dan tentu saja hal ini mendatangkan malapetaka. Manusia hanya berorientasi pada bagaimana kehidupannya terus berlanjut padahal keberlanjutan kehidupannya sangat bergantung pada ketersediaan ciptaan lainnya. Jika demikian manusia gagal dalam perannya sebagai co-creator yang menghadirkan cinta Allah dan cintanya bagi sesama ciptaan.

Tak ada jalan lain bagi manusia kecuali menjadikan pola hidup Sang Manusia yakni Yesus Kristus sebagai jalan kehidupan. Hidup dalam spiritualitas Yesus akan selalu menjadikan manusia sebagai something dalam tangan Allah bagi kehidupan. Hanya dengan begitu kehadiran manusia menjadi Injil bagi segala makhluk.

\section{Catatan Akhir:}

\footnotetext{
${ }^{1}$ Emanuel Gerrit Singgih, Dari Eden ke Babel,(Yogyakarta : Kanisius, 2014), hlm. 179

${ }^{2}$ Ibid, hlm. 183

${ }^{3}$ Ibid, hlm. 215

${ }^{4}$ Ibid, hlm.213

${ }^{5}$ Ibid, hlm. 226

${ }^{6}$ Pipi Agus Dhali, Dari Eden sampai ke Gosyen, Sebuah Ziarah Rohani Bersama Kitab Kejadian, (Jakarta : Hodos Publishing, 2013), hlm. 24

${ }^{7}$ Saya menyebutkan bahwa "semua yang diciptakan kehilangan kepekaan akan cinta Tuhan", bukan "kehilangan cinta Tuhan" sebab manusia lah yang memilih untuk mengikuti kehendaknya sendiri ke arah yang salah dan karena pilihan itu, manusia tidak dapat menikmati cinta Tuhan.

${ }^{8}$ Emanuel Gerrit Singgih, Opcit, hlm. 228

${ }^{9}$ Adrianus Sunarko, Teologi Kontekstual, (Jakarta : Obor, 2016), hlm.99

${ }^{10}$ Emanuel Gerrit Singgih, Opcit, hlm. 52

${ }^{11}$ Emanuel Gerrit Singgih, Berteologi dalam Konteks, (Jakarta : BPK Gunung Mulia dan Yogyakarta : Kanisius, Pustaka Teologi,2007), hlm. 248

${ }^{12}$ C. Groenen, Kristologi dan Allah Tritunggal I, dalam Kristologi dan Allah Tritunggal, ed. J.B. Banawiratma, (Yogyakarta: Kanisius, 1986), hlm.32

${ }^{13}$ G.C. van Niftrik dan B.J. Boland, Dogmatika Masa Kini,(Jakarta : BPK Gunung Mulia, 2013), hlm. 186

${ }^{14}$ Ibid, hlm. 187
} 
${ }^{15}$ Emanuel Gerrit Singgih, Dari Eden Ke Babel, opcit, hlm. 310

${ }^{16}$ T. Tri Harmaji, Teologi Jalan Tengah, (Yogyakarta : Taman Pustaka Kristen, 2014), hlm. 120

${ }^{17}$ Anton M.Muliono, dkk, Kamus Besar Bahasa Indonesia,(Jakarta : Balai Pustaka, 2000), hlm.749

${ }^{18}$ Agus M. Hardjana, Religiositas, Agama \& Spiritualitas,(Yogyakarta : Kanisius, 2005), hlm. 79

${ }^{19}$ T. Tri Harmaji, Opcit, hlm. 147. Selanjutnya saya akan menguraikan dua prinsip yang dikemukakan oleh Harmaji tetapi dalam kaitannya dengan tanggung jawab terhadap ciptaan lainnya.

${ }^{20}$ Ibid, hlm. 151

${ }^{21} \mathrm{Ibid}, \mathrm{hlm} .78$

${ }^{22}$ BL Padatu, Wibawa Sepeda Ontel, (Surabaya : Capiya Publishing, 2010), hlm. 3,4

${ }^{23}$ Albert Nolan, Jesus Today Spiritualitas Kebebasan Radikal,(Yogyakarta : Kanisius, 2009), hlm. 45

${ }^{24}$ Josef P. Widyatmadja, Yesus Wong Cilik,(Jakarta : BPK Gunung Mulia, 2010), hlm. 179,180

${ }^{25}$ William Chang, Moral Lingkungan Hidup, (Yogyakarta : Kanisius, 2001), hlm. 90

\section{DAFTAR PUSTAKA}

Chang, William. 2001.Moral Lingkungan Hidup. Yogyakarta: Kanisius

Dhali, Pipi Agus. 2013.Dari Eden sampai ke Gosyen. Jakarta: Hodos Publishing

Groenen, C. 1986.Kristologi Dan Allah Tri Tunggal I, Yogyakarta: Kanisius

Harmaji, T.Tri. 2014.Teologi Jalan Tengah, Yogyakarta: Taman Pustaka Kristen

Hardjana, Agus M. 2005.Religiositas, Agama \& Spiritualitas.Yogyakarta:

Kanisius

Nitrik, G.C. van. dan Boland, B.J. 2013. Dogmatika Masa Kini.Jakarta: BPK Gunung Mulia

Nolan, Albert. 2009.Jesus Today, Spiritualitas Kebebasan Radikal, Yogyakarta: Kanisius

Singgih, Emanuel Gerrit. 2014.Dari Eden Ke Babel, Yogyakarta: Kanisius 2007.Berteologi Dalam Konteks, Jakarta: BPK Gunung Mulia dan Yogyakarta, Kanisius.

Sunarko, Adrianus, 2016.Teologi Kontekstual.Jakarta: Obor 


\section{KAMUS :}

Muliono, Anton M., dkk. 2000.Kamus Besar Bahasa Indonesia. Jakarta:

Balai Pustaka 